\title{
Use of Technology in Classroom for Professional Development
}

\author{
Fouzieh Sabzian \\ School of Educational Studies, University Sains Malaysia, Malaysia \\ Abbas Pourhosein Gilakjani \\ Lahijan Branch, Islamic Azad University, Lahijan, Iran \\ Sedigheh Sodouri \\ University of Isfahan, Isfahan, Iran
}

\begin{abstract}
Technology has modified the method of learning and teaching .Many learning theories can be used to apply and integrate this technology more effectively. There is a close relationship between technology and constructivism has got a close relationship. The implementation of each of these has merits for the other. Learning happens in situations, while technology focuses on the settings and programs which make learners be involved in. The latest efforts have been done to incorporate technology in classrooms based on the constructivist structure context. This paper aims at investigating. (a) benefits of the incorporation of technology into the classroom (b) successful technology integration into the classroom (c) factors cont ributing to teachers' use of technology (d) The application of learning theory by teachers to make technology more efficient (e) learning with technology: constructivist perspective and (f) constructivism as a framework for educational technology. This paper explains that if technology on its own can make the progress of education more efficient or not and if the existence of a complete instructional theory for technology is serious for indicating its positive effect on the learner is an important issue.
\end{abstract}

Index Terms-technology, constructivism, learning theory, teachers, professional development

\section{INTRODUCTION}

Although technology opens up novel chances for the appearance of the issues like styles of learning, student-oriented education and stimulates deeper levels of thinking, the teachers' mind-sets and beliefs, it often impedes the teachers to manage to incorporate the technology with their course designs and syllabus completely. Being such an uncertainty causes that technology is applied as an alternate for other tools in the traditional type of teaching instead of using new kinds and approaches to education (Judson, 2006). Many factors urge teachers to use computer technology in their classrooms. These factors include computer self-efficacy, personal technology use, positive teacher attitudes and beliefs towards technology and access to professional development in the computer technology area. All of these are significant in motivating teachers to use technology. Nevertheless, using technology in the classrooms as a means of instruction would be useful by the teachers if they are supported by appropriate educational theories and models.

Many researchers have investigated the effect of constructivism on classroom practices to know how technology usage and application in the classrooms can potentially increase the process of teaching and learning (Richards, 1998; Brush \& Saye, 2009). There is a close relationship between technologies and constructivism, the implementation of each one benefiting the other.

According to Schunk (2000) constructivism is a 'philosophical and psychological approach' which is built upon 'social cognitive' proposes that individuals, conducts and atmosphere are in a mutual interaction. States that learning happens in situations where learners form what they have learnt mostly and consider it as a task of their experience in situations.

Technology is the means and atmospheres that engage students. Constructivism and technology both center on the formation of learning situations and atmospheres. The learning settings are like atmospheres where tools of knowledgebuilding are provided to produce and influence the art of understanding though which students have a team work and support one another as they utilize different tools and learning resources in their search for learning aims and activities for solving problems. The learning settings are like atmospheres where tools of knowledge-building are provided to produce and influence the art of understanding though which students have a team work and support one another as they utilize different tools and learning resources in their search for learning aims and activities for solving problems (Hannfin \& Hill, 2002).

In this paper, the researchers explain the benefits of the incorporation of technology into the classroom, elaborate successful technology integration into the classroom, discuss factors contributing to teachers' use of technology, state 
teacher's use of learning theories, examine constructivist perspective, and investigate constructivism as a structure of educational technology.

\section{BENEFITS OF THE INCORPORATION OF TECHNOLOGY INTO THE CLASSROOM}

Several researchers have performed studies in an attempt to find out if the incorporation of technology into the classroom helps students, and if so, what factors contribute to a positive outcome (Dawson, Cavanaugh \& Ritzhaupt, 2008). These researchers have looked at individual pieces such as the effects of specific software use with reading and mathematics curriculum, while other research focuses on the overall impact of installing and using computer- based technology in the classrooms. The important thought to keep in mind is that the interest of researchers on the effects of technology on education has been flourishing in the past years giving teachers the ability to explore these new waters and adapt their teaching accordingly. There is enough variety among recent authors to warrant the making of generalizations that can be applied to any current classroom situation. One of these generalizations states that the introduction of technology into the classroom environment exerts a change in the way students learn.

For the most part, the changes take on a positive direction by creating a learning atmosphere centered on the student rather than the teacher.This is because replacement of the traditional seat-work to some extent traditional seat-work with the use of computers as learning tools. Instead of the static teacher-centered environment where the students act as receivers of information from a single source, the classroom becomes an active setting full of meaningful activity where the student is made responsible for his or her learning. The students are engaged in meaningful activities such as problem-based learning projects, browsing the Internet in search of information for a report, or the preparation of presentation assignments. Software and hardware become tools used by the student to create a product to be presented to teachers and fellow students so that they may review, learn, or critique in a collaborative manner (Dawson, Cavanaugh \& Ritzhaupt, 2008).

All of these factors create an increase in student interest and engagement with the subject being studied, and high student attention to independent research. The teacher takes the role of a facilitator who directs students to an achievable goal. Teachers work with students in such a way that there is an increase in critical thinking skills and the use of the computer as a learning tool. They make practical choices of tools and media that will shape the way students learn, express themselves and perform (Drayton, Falk, Hobbs, Hammerman, \& Stroud, 2010).

Another positive and desirable effect of bringing technology into the classroom is the increase in collaboration among teachers and students. This expanded interaction is manifested through the frequent trading of computer skills, shared tips about technology, and the role of the student as a tutor. By allowing students to become assistants in the instruction process their self-worth and confidence increase. They are granted the opportunity to reinforce ideas and skills already learned. These are competencies that are not necessarily shared only with other students. In fact, often the student is able to help the teacher on technology tips that the student has had the time to master while the teacher works on directing the instruction as a whole (Mouza, 2008). This adds to the learner's increase in meaningful use of technology and collaborative participation. The forgoing description of the computer-based classroom represents an authentic learning experience that fosters student responsibility. Teachers report that the introduction of systems such as the Internet and e-mail encourages student-directed learning and the acquisition of responsible behaviours (Drayton, Falk, Hobbs, Hammerman, \& Stroud, 2010).

This is due in part to the fact that students do not need to rely on the teacher to locate new sources of information and they can use email to place their homework and projects on a location that is available at all times. In addition, the independent use of the Internet gives the student a certain amount of self- direction.

Once they have received general parameters for working on a specific project, the students can determine the route for achieving the goal presented by the teacher. Another benefit of the computer-based classroom is the increase in student motivation. Research data demonstrate that students in a classroom with laptops are enthusiastic about having the technology and find learning environment more enjoyable than students who do not work with laptops. These students often go beyond the requirements set forth for any given assignment and show increased academic engagement. Increase in motivation leads to the creation of sophisticated activities such as different types of written expressions, multimedia products, and the analysis of data. A sense of pride and empowerment becomes characteristic of the participants (Mouza, 2008).

All the benefits of technology presented so far converge on student achievement on subject areas and evaluations. How do students in computer-based classrooms perform and score on tests? Research has concluded that when students are engaged in technology-immersed classrooms, there is a gain in achievement in all subject areas (Wenglinksy, 1998; Means, 2010; Shapely, Maloney, \& Caranikas-Walker, 2010).

Wenglinksy (1998) came to this conclusion that using computers in mathematics by eighth grade students was significantly related to academic achievement and the social environment of the school. However, he stipulated that greater student scores might be achieved when students use computers to apply higher-order skills such as solving simulations rather than drill and practice exercises.

Shapely, Maloney, and Caranikas-Walker (2010) report on an extensive study performed on 21 treatment schools. The purpose of the research was to evaluate technology immersion in these middle schools and the corresponding effects on test scores and data was collected for four years. 
The use of technology in the classroom correlated with test scores but the result was positive only in schools where the immersion program was implemented with higher level of fidelity. Thus, the actual implementation of the program was a predictor in the test. Schools that implemented the program first enabled their students to reach higher test scores. The authors acknowledge that positive attitude towards the utilization of technology in classrooms will draw the greatest advantage.

Computer use in the classroom correlates to improved achievement on the part of the student but Means (2010) cautions that technology alone is not a cure for poor scores. She reports on a research project that sought to find out what elements of technology use in the classroom truly affect student scores.

The process included thirteen schools that had adopted reading and mathematics software to complement their core curriculum. Seven schools had achieved high scores in both reading and mathematics, while the other six had scored poorly. The data collected during this study concluded that the software itself was not responsible for higher or lower achievement. Instead, elements such as a reliable educational look, main support, teacher cooperation, and pleasing onsite technical backups were essential for achieving an acceptable learning experience and competent test scores. In addition, Means suggests that the data confirms that classroom management and weekly review of software reports for all students are major assets of a successful program using reading and mathematics software (Means, 2010).

\section{SUCCESSFUl TECHNOLOGY INTEGRATION INTO THE ClaSSROOM}

Gorder (2008) stated that successful technology integration is what makes a difference in reforming a classroom. Integrating technology is not easy, it is a three step process that involves the teacher learning the technology and using the technology in teaching and learning so that student learning is enhanced.

Effective technology integration can be affected by certain factors. Hew (2007) identified six factors that affect successful technology integration. They are lack of resources, lack of specific knowledge and skills, institutional structures, teacher attitudes and beliefs toward technology, and types of assessment and subject culture. The changes in computer-based technologies over the last ten years have been incredible and it is difficult for schools and universities to stay in step with the current industry norms. Computers that were top of the line five years ago are horribly outdated today. Updating computer resources is extremely expensive and combined with the budget constraints that schools and universities are now facing with and it is no wonder that many institutions lack current technological resources.

Time is another resource that is severely lacking. Unfortunately, teachers are finding a decreasing amount of time allowed for preparation while responsibilities increase. This occurs in spite of the fact that technology integration is demanding more time, including searches for appropriate websites, preparing PowerPoint presentations, downloading videos, and more. Therefore, teachers need more time to prepare and they are required to be on-site to provide technical support in order to offer a quick and adequate response when computers fail (Hew, 2007).

According to Hew (2007) teachers need specific technological teachers need specific technological information and know-how for the purpose of using computer-based technologies in teaching? It is not enough for specialized progress to stress on the method of operating a specific program but additionally there needs to be guidance in how to use the program to increase student learning. Emphasis also needs to be placed on classroom management as it relates to computer-based technologies. Additional rules and procedures need to be incorporated once computers, printers, and other electronics are added to the classroom mix.

Institutional factors such as lack of planning on the part of the administrators further hinder technology integration according to Hew (2007). For instance, there was a certain administrator who proudly announced at a staff meeting that the school had recently acquired two computers that could be checked out for classroom use. There was no mention of who could instruct the teachers on how to use them or even what were the computer capabilities. A better mode of introduction could have been for the administrator to plan ahead and serve as a role model by demonstrating the use of a computer at the staff meeting. Teacher attitudes and beliefs are another factor on the road to successful technology integration. Teachers should be exposed to research that focuses on technology integration benefits. If a teacher views computer-based technology as another form of babysitting, he or she will use it that way. Conversely if teachers believe that integrating technology enhances student learning they will find ways to use this technology in their classrooms.

What can schools and universities do in order to integrate technology successfully. Hew (2007) has some suggestions. Institutions' administrators and teachers need to join together to implement a technology plan that considers integration strategies along with purchasing decisions. Professional development needs to be at the forefront in order to assure student learning and to change the attitudes and beliefs of teachers unfamiliar with the benefits that technology has to offer. And finally, the technology plan must be closely aligned with the curriculum standards. Teachers need to know what instructional approach is the most effective when integrating computer- based technologies in the classroom.

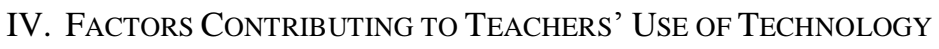

In this section, the researchers review the researchers' review the elements that affect teachers use of technology in the classes. They also try to find the relationship between technology use and teaching performances. The introducing technology in the design and syllabus of classes is remarkable, particularly, by considering the effect of computers and internet it has on the new generation of learners who enter the educational system. According to Oblinger (2003), 'the 
millennial generation' or the students who were born after 1982, is different from their former generation in noticeable features. The new ones incline to approach towards group activity and are interested to new technologies. They are actively fascinated by playing online video-games and chatting. This is what is opposite to the traditional lecture style that the older generation of the teachers believes in most classrooms. The method of learning for the new generation is centered on group work, empirical and multitasking activities, and using the technology. For the new generation of learners, technology is regarded as an integral part of their daily lives in their environments. Younger learners are more apt to the higher extent of contact to technology and internet usage which leads to many differences between learners learning methods and the teachers' knowledge and aptitude to use technology (Oblinger, 2003).

Students who were involved in the program of teacher training were not enough in the exposure of technology integration as a part of the program for teacher training, but they showed a positive outlook to teaching while using technology Brown and Warschauer (2006) came to the point that university lecturers or instructors need to upgrade their skillfulness in technology to the level they can mingle the new technology in their teaching to promote their students' thinking skills to a higher level. The Using technology to advance learning in a higher level can only happen when the teachers who teach in classrooms are trained to comprise new technologies and mix them carefully with their curricula (Brown \& Warschauer, 2006). Brown and Warschauer (2006) advocate the blending of learning about technology with teaching methodology and assigning advisors who are proficient in technology for teachers to develop teachers' skills of technology during their teaching practicum.

A variety of factors affect teachers who use technology in their classrooms Both in their pre-service training program, their personal lives and while they do the teaching as their profession that have influenced them to do so. Taking technology courses in the teachers' undergraduate program is one of the influential factors in teacher technology use. Given teachers are appropriately trained to use technology before entering a real situation setting for teaching, i.e. classroom, their effectiveness will raise, and they are more likely to use technology in the classrooms. Some studies have demonstrated that those teachers who have participated the pre-service training programs and educational technology courses with the emphasis on the using technology skills as a part of their lesson plan, can improve their effectiveness and self-efficacy in their pre-service technology skills (Koh \& Frick, 2009).

There is a positive relationship between a teacher's computer self-efficacy and technology integration in the classroom (Koh \& Frick, 2009). In a study conducted by Hernandez-Ramos (2005) he notes that since technology is frequently used by youth these days, sometimes student knowledge of technology can trump teacher knowledge. In these cases the teachers' roles as the skillful and students' as the amateur can often be exchanged and may cause that some teachers feel uncomfortable by this condition, because most of the teachers tend to have mastery over the students in using technology in their classrooms. Based on a survey, 55\% of teachers stated that they strongly agree with this statement that "A teacher's proficiency with computers will affect his or her willingness to integrate technology into the curriculum" (Hernandez-Ramos, 2005, p. 47).

According to Wozeney (et.al, 2006), if the teachers outside the classrooms use computer, it can be an indicator of a teacher's use of technology in the classroom. In a study conducted by Hernandez-Ramos (2005), teachers were asked about the time they had spent with their personal computers. The teachers showed that they have used a mixture of eleven kinds of software use. They also were asked to evaluate and mark their knowledge of each one. The findings of this study proved that those teachers who had a good command of knowledge on these eleven software usage, allowed their students to use computers one day more in a week compared to the teachers who were not enough skilled on average. The findings of this study also indicated that given the teachers use the computers at home more often, they are at ease with using computers in the classroom. The teachers' positive beliefs and outlooks to computers causes that they apply technology efficiently in the classroom (Christensen, 2009). Some of these positive beliefs and outlooks spark the expectation that the teachers will be able to apply the technology effectively and use of technology in the classrooms will also benefit students' learning better (Wozney et al., 2006).

Other important factors that help teachers use technology in teaching include modeling by colleagues, expectations by the administration of academic institutions, positive experiences with computers in teaching, and teacher beliefs and attitudes about technology in teaching. Researchers have shown that a key factor in encouraging teachers to introduce and sustain the use of multimedia in classroom instruction is modeling (Alvine, 2000; Becker, 2000; Bowman, 2000; Bullock, 2004; Aust et al., 2005). In research with high school teachers engaged in professional development for technology integration in the United States, Bullock (2004) found that lack of modeling by the mentor teacher was a disabler while modeling concrete uses of technology in specific subject areas and grade levels was found to be an enabler. In addition to effective mentoring, encouragement, and modeling, Bullock found that clear expectations, easy access to technology and technical support, and positive experiences with computers in classroom settings facilitated the necessary skill development for teachers to use technology on a regular basis.

Adamy and Heinecke's research found that three important factors that need to be operational: (a) access to hardware, software, and technical support; (b) teacher educators' relationships with key technical players; and (c) positive institutional attitudes toward technology use emphasizing the institutional context in which technology novelty occurs Adamy and Heinecke (2005) suggest that technology integration is a social process that must be equipped with organizational institutional support to be successful. Another factor contributing to teachers' use of multimedia is an attitude toward educational technology. Howland and Wedman (2004) surveyed pre-service secondary level teachers 
learning to use technology in their classrooms. Instead of viewing technology as a collection of skills to be acquired, the ideology of life-long learning emerged with pre-service teachers developing self-concepts of themselves as technology users. Bowman (2000) declares that most teachers who use multimedia understand that technology does not replace good teaching; instead it opens new horizons for discovery and exploration. Furthermore, teachers should not attempt to use technology for technology's sake; for example, implementing computers in classroom settings for repetitive drills which are devoid of contextual grounding.

Another contributing factor for teachers' use of multimedia is promoted by Alvine (2000) who emphasizes the view that technology should be a tool for learning content, instead of making technology the content. Alvine (2000) endorses the need for teachers to rethink uses of technology. Further, Alvine (2000) suggests that we can model an orientation toward embracing the new and being careful in our critical review of its impact on the teaching and learning. Most teachers would agree, as Alvine (2000) suggests, that the classroom needs to be a human community that prepares students to live in the real world which is becoming increasingly technology-based. It is necessary to rethink the length of time it takes for teachers to become accomplished in using computers in classroom instruction (Sheingold \& Hadley, 1990). Sheingold and Hadley stipulated that it takes five to six years of collaboration with colleagues in a functional technological environment to achieve the integrated use of multimedia curriculum. Thompson (1999) supported this position and noted that the used technologies in teaching are not impartial applications that easily direct the student; rather the tools of educational technology are the inventions of social shaping per se and are shown in the reproduction of social knowledge and equalities.

Dupin-Bryant (2004) asserts the view that teachers who are using instructional technology in classroom settings need high-level support from experts to keep hardware running and to learn various software programs. Peer mentoring, peer workshops, electronic message boards can inspire and support teachers involved in multimedia curriculum development. Teaching styles, like learning styles, are highly personal and influenced by intrinsic and extrinsic factors (Machnaik, 2002; Burnston, 2003). A re-visioning of educational goals is one of the needed organizational and/or systemic changes required (Dillon \& Morris, 1996). Carroll, Rosson, Dunlap, and Isenhour (2005) studied human-computer interactions and affirmed that the sovereignty culture has come under stress in the past ten years giving way to a culture of collaboration. The research by Carroll et al.(2005), marked knowledge sharing in three levels of knowledge sharing which involved: (a) tangible resources (websites, lab equipment); (b) plans and objectives (lesson plans, worksheet templates); and (c) prototypes (online reports, project summaries, and photos). This collaborative model, facilitating the functional use of technology in education, is in direct contrast to the isolation typical of traditional teachers who manage their own resources and rarely share their pedagogical practices.

With respect to teachers' personal factors, it is concluded that teachers' perspectives and understandings of technology utilization influence their technology utilization in teaching (Cuban, Kirkpatrick, \& Peck, 2001; Zhao \& Cziko, 2001; Parks et al., 2003; Chen, 2004; Judson, 2006; Wozney, Venkatesh, \& Abrami, 2006; Dudeney \& Hockly, 2007; Liu \& Huo, 2007; Park \& Son, 2009). For instance, if teachers think that technology can be a menace to their traditional method of teaching, i.e. teacher-oriented method in which they have been trained for long years, they refuse to accept technology utilization (Liu \& Huo, 2007). Likewise, if teachers accept this revolution of educational technology little by little or an instrumentalist view of change, they will accept to use technology but for the purpose of teaching preparation and communication (Cuban, Kirkpatrick, \& Peck, 2001).

In a study on the discrepancy between teachers' presumptions and actions in technology integration in Taiwan, Chen (2004) found that reasons for the inconsistency include teachers' restricted or inappropriate theoretical perception on student-centered teaching and technology integration or know how to transfer theoretical concepts on technology integration into practice, e.g., how to plan technology-based learning practices that would simplify and ease students' active knowledge building; and teachers' other conflicting beliefs such as the conflict between the pressure to cover content due to the test-driven culture and the need to allow students to explore content through technology.

Teachers' technology use is also proved to be in relation to their expectation of success and understood worth of technology. Wozney, Venkatesh, and Abrami (2006) discovered that teachers who believed they are skilful enough to use computers successfully and who worth the results related with their integration happened to be considered as high technology users' spectrum. In a similar study of English as a Foreign Language (EFL) teacher's using technology in their classes in Korea , Park and Son's (2009) study showed that internal matters like teachers' lack of enough skill in computer knowledge and their perspectives about computer assisted language learning has had a drastic affect on their decision on how to use technology in education. Besides teacher perspectives and understandings in this regards, Wozney, Venkatesh, and Abrami (2006) also showed that personal utilization of computers by teachers outside their classes was the most important index for their technology use inside the classrooms. That is, teachers' access to computers outside of teaching has a positive influence on their computer use in the classroom. Hence, to know about teachers' practices in using technology in their teaching, it is vital to study their supposed value of technology and their competence and proficiency in technology along with their outside-classroom use of technology. Another personal and important factor includes the relationship between teachers' educational activities (for example, their teaching methods) and use of technology.

In a similar study done by Wozney, Venkatesh, and Abrami (2006) in the province of Quebec, Canada, 2213 teachers' were asked about their opinions about using technology in the classes. The findings of this study reported that 
teachers who more welcome student-oriented methods are more often expected to incorporate computer technologies and they consider it as a more complicated phase of incorporating computers in the classrooms. Unlike to these findings, several studies (Chen, 2004; Judson, 2006) have suggested that there is a distinction between teachers' stated teaching methods and their use of technology in the classrooms. In a study on 47 teachers in the U.S, Dexter, Anderson, and Becker (1999) reported that teachers who used more student-centered progressive teaching activities, did not view technology as a catalyst for change in their educational activities. Likewise, Chen (2004) discovered high degree of harmony on student-centered concepts among the studied Taiwanese teachers, but subjects' teaching remained teacheroriented and lecture-based and for them utilizing technology was to back such a teaching. The opposing findings from different countries and contexts put forward more research is needed to investigate the relationship between teachers' educational thoughts, perspectives and technology use.

\section{Teachers’ Use of Learning Theory Makes TeChnOlogy More EfFective}

Neither using technology nor a learning theory independently makes a productive class. To have a methodology for technology-based learning technology need to be supported by a learning theory (Muniandy, Mohammad \& Fong, 2007). In most of the classes today, teaching happens based on old theories of learning where technology is utilized only as an instrument in changing traditional tools. For example teachers use PowerPoint slides in the classroom instead of writing on the board or using written texts and passing them out in the classrooms. This question is raised that can technology per se make the classrooms more efficient or is a model or teaching theory to incorporate technology effectively needed? Do we have to have a proper theory of learning as a framework in which our teaching result (learner) can be more innovative and fruitful? (Rakes, Fields \& Cox, 2006). The results of this research show that teachers cannot depend on technology tools or learning theory by themselves. To have a prolific classroom atmosphere these two variables should be combined to make the class atmosphere prolific that do technology tools become better if supported by learning theories?

\section{LeARning With TeChNOlogy: Constructive PeRsPective}

Jonassen and Reeves (1996) differentiate between learning from and learning with computers. Many recent studies and development on technologies took the increased learning into account that were possible to be obtained while computers had a significant position in delivering content and making learning chances to assist learners make meaning and promote a thought. In such circumstances, teachers played a very moderate role. Jonassen (1991) proposes that the if the use of technologies is opportunistic and successful in classrooms and the learning achieved with the aid of technology, then result would be the existence of a setting in where learning is supported and scaffolds by technology not being 'the object or derivative of learning'. As McClintock (1992) put forward, in a constructivist-learning situation, technology plays a decisive role in everyday activities but does not become the means of teaching, in a constructivistlearning method (Jonassen, Peck \& Wilson, (1999).

According to Lajoie and Derry (1993), the technological utilization which support learning in such ways are mostly explained as cognitive tools and more studies are now proving the merits to be obtained from such utilizations. Cognitive tools explain such utilizations as (a) calculators, (b) databases, (c) spreadsheets, (d) communications software, (e) semantic network tools, and (f) knowledge construction tools. The decisive trait of cognitive tools does not exist in the information and knowledge that they have, but the kinds of student activities and involvements that they support and promote. Cognitive tools still need the learned teachers to plan and monitor the learning activity, but they perform to increase and hand out the cognitive tasks through their tools and learning atmospheres that have been "adapted or developed to function as intellectual partners with the learner in order to engage and facilitate critical thinking and higher-order learning" (p. 11). As the author noted, the role of a mind-tool is to broaden the students' cognitive functioning while they are learning and to take on the students on tasks while making knowledge that they have not managed to acquire otherwise. Mind-tools make the students capable of becoming critical thinkers. By making use of cognitive tools, learners are also engaged in knowledge creation rather than knowledge reproduction. Learners utilize the available software to use technology to both make and show knowledge.

Computers manage successfully to increase learners' problem -solving skills by utilizing project-based learning (PBL) practices; since they are employed in a setting where people are drawn to cooperate naturally as a result of their cultural opportunities. Tretten and Zachariou (1995) carried out an evaluation of PBL in four elementary schools by administering teacher questionnaires and interviews, and a study of parents. The cognizant stated that PBL had a range of positive advantage $\mathrm{s}$ for learners like as views to learning, work habits problem-solving abilities and confidence. Ryba and Brown (2000), concluded that teachers' idea s on themselves and their roles in the classroom, and their attitude of teaching had a key position in forming the characteristics of their computer use. The teachers who monitored learner-oriented classrooms and real learning activities as a key to the success of their students were more probable to utilize the technology on an ongoing basis. Means and Olson (1997) found that technology enlarged the intricacy with which learners could deal successfully and made multiple roles and tasks, causing to student specialization. It led in profound exploration of a limited number of views and related facts around genuine and demanding activities. They mention that when learners utilize technology as an instrument or support for making relationships with others, they 
play an active role not a passive one of the information receiver conveyed by a teacher, course book, or broadcast. The learners are actively choosing about how to produce, get change, or show information.

Hypermedia let users to go into virtual settings that contain text, sound, visual images, animation, and video. Riddle (1995) investigated that students using hypermedia indicated that augmented aptitude to transfer insight and individuality, larger explanatory details, and unique viewpoints. In the USA, The Challenge 2000 Multimedia Project baked by multimedia gives students chances to use technology effectively in the designing, progress, and staging their assignments. Students who participated in this project obtained better results compared to students who gained mastery on content, addresses sensitivity and sound plan design (Thomas, 2000).

\section{CONSTRUCTIVISM AS A FrAMEWORK FOR EDUCATIONAL TECHNOLOGY}

As Judson (2006) reported in his paper that there is a relation between teachers who use constructive teaching methodology and technology utilization in the classroom. According to facts, constructivist teachers tend to use technology in their classrooms and incorporate technology to their courses more frequently than the teachers who follow other learning doctrines. The correlation between teachers with learner-oriented ideas about teaching and the frequency of their using technology as method of enhancing learners' learning is positive. The relationship between technology utilization and constructivist teaching activities seem to create the best usages of technology tools to ease the lesson design. Rather than being restricted as a part of the existing traditional approach, by using constructivist theory, technology appear s to change every dimension of teaching or instruction. From course planning to the ways of delivery and even evaluation (Rakes, Fields \& Cox, 2006). The tendency not to utilize technology in learning settings, but to let the technology to change the teaching methodology is not regular among the teachers nowadays. The teachers' inclinations to apply the constructivist teaching methods enhance the probability that teachers' use incorporates technology in the classrooms (Rakes, Fields \& Cox, 2006).

In a study conducted by Hernandez-Ramos (2005), the participants of the study who were teachers in the Silicon Valley in California were asked about the factors affected their use of technology in the classroom. Results of the study proved that there are three main factors affected teachers' technology incorporation practices: 1) if teachers had been prone to technology in their teacher training programs, technology was utilized more often by both teachers and learners than in other classes. 2) The teachers who had an understanding of software usages used technology more often in their classes. 3) Teachers believing in constructivism used technology more often in their classrooms. Their students also used technology more often than those teachers and students who did not utilize technology. Constructivist teachers use their teaching methodology inspiring from the old Chinese saying: "Tell me and I will forget; show me, and I may remember; involve me and I will understand". This statement stresses that students' engagement in the learning is the best strategy.

Constructivist teachers support their students' use of technology as it helps them make their own perception of information by integrating real experiences into task-based learning settings. Boethel \& Dimock (1999) contended that when teachers mix technology constructivist learning situations, learners' accomplishments is absolutely tightly wedged in (Hernandez-Ramos, 2005). Hernandez-Ramos followed constructive beliefs to design his study. Then he made a scale based on that. By using this scale, he compared teacher groups who gave the "yes" answer to the question "Have you ever created technology-based projects for students?" with those who answered "no". Teachers who showed that they "integrate technology into their lessons whenever possible" marked notably higher on the constructivist belief scale than their colleagues who did not. Findings showed a positive relationship between the teachers who utilized technology more frequently (4-5 days per week) in their classes and constructivist beliefs.

\section{CONCLUSION}

Just adding a technology tool to a traditional teaching approach does not produce more effective instruction and make the process harder and more complex without providing much benefit. In order for technology to be used effectively in the classroom, teachers have to make sure that they are using it as part of an approach that involves the students in the activity. Constructivist approaches which highlight learner-oriented learning have supported for a long period that students are required to be engaged in the process of acquiring knowledge and have looked for methods for teachers to become upholders in process of learning rather than as persons who solely prescribe information his approach appear $\mathrm{s}$ to have a good correspondence the utilization of technology which are developed nowadays. Utilizing technology does not necessarily mean that one should firmly be a supporter of constructivism, since it is essentially not persuasive for the group of teachers who still believe in traditional methods of teaching, and these two approaches are inclined to enhance the other and give the best results from both utilization and a theoretical approach. The technology utilized in the classrooms based on the constructivist method, students are engage $d$ in activities that they can structure the instruction to satisfy various levels and methods of learning. They also can extend the variety of resources which are presented to students. This allows the technology to be more than one method of offering information. Technology then becomes the method through which information is depicted and realized. Technology is regarded as a part of theory of learning and it is viewed more than a tool; it becomes the methodology framework. For the people who are seeking for approaches to increase their constructivist approach to teaching, technology presents them the capability to advocate all 
of the core themes of the constructive theory and technology. As technology assists the teachers to plan their teaching materials in a way that supports their theoretical approach, they get less reluctant to utilize technology. The better application is that both constructivist theory and technology are integrated in the classrooms effectively, since it prepares the tools which are vital for teachers to plan a teaching model that satisfies the requirements of a learneroriented spotlight.

\section{ACKNOWLEDGMENT}

We thank Seyedeh Masoumeh Ahmadi, Ebrahim Davoudi, Alizadeh, and Babaee for their extensive and insightful discussions and comments on the paper.

\section{REFERENCES}

[1] Adamy, P., \& Heinecke, W. (2005). The influence of organizational culture on technology integration in teacher education. Journal of Technology and Teacher Education, 13(2), 233-244.

[2] Alvine, L. (2000). A 20th century English teacher educator enters the 21st century: A response to Pope and Golub. Contemporary Issues in Technology and Teacher Education, 1(1), 102-106.

[3] Aust, R., Newberry, B., O'Brien, J., \& Thomas, J. (2005). Learning generation: Fostering innovation with tomorrow's teachers and technology. Journal of Technology and Teacher Education, 13(2), 167-180.

[4] Becker, H. J. (2000). The exemplary teacher' paper: How it arouses and how it changed its author's research program. Contemporary Issues in Technology and Teacher Education, 1(2), 1-9.

[5] Bowman, C. A. (2000). Infusing technology-based instructional frameworks in the methods courses: A response to Pope and Golub. Contemporary Issues in Technology and Teacher Education, 1(1), 98-101.

[6] Brush, T., \& Saye, J. W. (2009). Strategies for preparing pre-service social studies teachers to integrate technology effectively: Model and practices. Contemporary Issues in Technology and Teacher Education, 9(1), 46-59.

[7] Brown, D., \& Warschauer, M. (2006). From the university to the elementary classroom: students' experience in learning to integrate technology in instruction. Journal of Technology and Teacher Education, 14(3), 599-621.

[8] Bullock, D. (2004). Moving from theory to practice: An examination of the factors that pre-service teachers encounter as they attempt to gain experience teaching with technology during field placement experiences. Journal of Technology and Teacher Education, 12(2), 211-224.

[9] Burnston, J. (2003). Proving IT Works. CALICO Journal, 20(2), 219-226.

[10] Carroll, J. M., Rosson, M. B., Dunlap, D., \& Isenhour, P. (2005). Frameworks for sharing teaching practices. Educational Technology and Society, 8(3), 162-175.

[11] Chen, C. (2004). Why do teachers not practice what they believe regarding technology integration? Journal of Educational Research, 102(1), 65-75.

[12] Cuban, L. (2001). Oversold and underused: Computers in the classroom. London: Harvard University Press.

[13] Dawson, K., Cavanaugh, C., \& Ritzhaupt, A. (2008). Florida's EETT Leveraging Laptops Initiative and its impact on teaching practices. University of North Carolina at Wilmington, 41(2), 143-159.

[14] Dexter, S. L., Anderson, R. E., \& Becker, H. J. (1999). Teachers' views of computers as catalysts for changes in their teaching practice. Journal of Research on Computing in Education, 31, 221-238.

[15] Dillon, A., \& Morris, M. G. (1996). User acceptance of information technology: Theories and models. Journal of the American Society for Information Science, 31, 3-32.

[16] Drayton, B., Falk, J. K., Stroud, R., Hobbs, K., \& Hammerman, J. (2010). After installation: Ubiquitous computing and high school science in three experienced, high-technology schools. Journal of Technology, Learning, and Assessment, 9(3).

[17] Dudeney, G., \& Hockly, N. (2007). How to teach English with technology? Harlow: Pearson Education Limited.

[18] Dupin-Bryant, P. A. (2004). Variables related to interactive television teaching style: In search of learner-centred teaching styles. International Journal of Instructional Technology and Distance Learning, 1(4), 3-14.

[19] Gorder, L. M. (2008). A study of teacher perceptions of instructional technology integration in the classroom. Delta PI Epsilon Journal, 2, 63-76.

[20] Hernandez-Ramos, P. (2005). If Not Here, Where? Understanding Teachers' Use Of Technology In Silicon Valley Schools. Journal of Research on Technology in Education, (38)1, 39-64.

[21] Hew, K. F. (2007). Integrating technology into k-12 teaching and learning: Current knowledge gaps and recommendations for future research. Educational Technology, Research and Development, 55, 223-252.

[22] Howland, J., \& Wedman, J. (2004). A process model for faculty development: Individualizing technology learning. Journal of Technology and Teacher Education, 12(2), 239-251.

[23] Jonassen, D. (1991). Objectivism vs constructivism: Do we need a new philosophical paradigm?, Educational Technology, Research and Development, 39(3), 5-13.

[24] Jonassen, D. H., \& Reeves, T. (1996). Learning with computers: Computers as cognitivetools. In D. H. Jonassen (Ed.), Handbook of Research for Educational Communications and Technology (pp. 693-719). New York: MacMillan.

[25] Jonassen, D. H., Peck, K., \& Wilson, B. (1999). Learning with technology: A constructivist perspective. Upper Saddle River, NJ: Prentice-Hall Inc.

[26] Jonassen, D. H. (2000). Computers as mind-tools for schools: Engaging critical thinking. Columbus, OH: Prentice-Hall.

[27] Judson, E. (2006). How teachers integrate technology and their beliefs about learning: Is there a connection? Journal of Technology \& Teacher Education, (14)3, 581-597.

[28] Koh, J. H. L. \& Frick, T. W. (2009). Instructor and student classroom interactions during technology skills instruction for facilitating pre-service teachers' computer self-efficacy. Journal of Educational Computing Research, (40)2, 211-228.

[29] Lajoie, S., \& Derry, S. (1993). Computers as Cognitive Tools. LEA: Hillsdale, NJ. 
[30] Liu, M., \& Huo, H. (2007). Computer Assisted Language Learning (CALL) in China: Some common concerns. US-China Foreign Language, 5(1), 52-58.

[31] Machnaik, J. (2002). Investigating the effect(s) of technology integration on teaching practices that may lead to the development of a community of learners (Electronic version). Saskatoon, SK, Canada: University of Saskatchewan.

[32] McClintock, R. (1992). Power and pedagogy: Transforming education through information technology. New York: Teachers College Press.

[33] Means, B. (2010). Technology and education change: Focus on student learning. Journal of Research on Technology in Education, 42(3), 285-307.

[34] Means, B., \& Olson, K. (1997). Technology and education reform. Washington, DC: U.S. Department of Education.

[35] Mouza, C. (2008). Learning with laptops: Implementation and outcomes in an urban, underprivileged school. Journal of Research on Technology in Education, 40(4), 447-472.

[36] Muniandy, B., Mohammad, R. \& Fong, S. F. (2007). Synergizing pedagogy, learning theory and technology in instruction: How can it be done? US-China Education Review, (34)4, 46-53.

[37] Oblinger, D. (2003). Boomers and gen-xers millennials understanding the new students. Educause Review, 38(4), $37-47$.

[38] Park, C. N., \& Son, J. B. (2009). Implementing computer assisted language learning in the EFL classroom: Teacher perceptions and perspectives. International Journal of Pedagogy and Learning, 5(2), 80-101.

[39] Parks, S., Huot, D., Hamers, J., \& Lemonnier, F. H. (2003). Crossing boundaries: multimedia technology and pedagogical innovation in a high school class. Language Learning and Technology 7(1), 28-45.

[40] Rakes, G. C., Fields, V. S. \& Cox, K. E. (2006). The influence of teachers' technology use on instructional practices. Journal of Research on Technology in Education, (38)4, 409-424.

[41] Richards, R. T. (1998). Infusing technology and literacy into the undergraduate teacher education curriculum through the use of electronic portfolios. T.H.E. Journal, 25(9), 46-50.

[42] Riddle, E. M. (1995). Communication through multimedia in an elementary classroom (Report No. 143). Charlottesville, VA: Curry School of Education, University of Virginia. (ERIC Document Reproduction Service No. ED 384 346).

[43] Ryba, K., \& Brown, M. E. (2000). How proficient IT teachers integrate computers into the curriculum. Journal of Computing in Teacher Education, 16, 6-11.

[44] Schunk, D. H. (2000). Learning theories: an educational perspective. New Jersey: Prentice-Hall.

[45] Shapley, K. S., Maloney, C., \& Caranikas-Walker, F. (2010). Evaluating the implementation fidelity of technology immersion and its relationship with student achievement. Journal of Technology, Learning, and Assessment, 9(4), 1-2.

[46] Sheingold, K., \& Hadley, M. (1990). Accomplished teachers: Integrating computer in classroom practice. New York: Bank Street College of Education, Centre for Technology in Education.

[47] Tretten, R., \& Zachariou, P. (1995). Learning about project-based learning: Self-assessment preliminary report of results. San Rafael, CA: The Autodesk Foundation.

[48] Wenglinksy, H. (1998). Does it compute? The relationship between educational technology and student achievement in mathematics. Educational Testing Service, Princeton NJ. Policy Information Centre.

[49] Wozney, L., Venkatesh, V. \& Abrami, P.C. (2006). Implementing computer technologies: Teachers' perceptions and practices. Journal of Technology \& Teacher Education (14)1, 173-207.

[50] Zhao, Y., \& Cziko, G. A. (2001). Teacher adoption of technology: A perceptual control theory perspective. Journal of Technology and Teacher Education, 9, 5-30.

Fouzieh Sabzian is a Ph.D. student of Education at the University Science Malaysia, Penang, Malaysia. Her main interests and experiences include teachers' training and technology. She has taught over 20 years at higher education and the Ministry of Education, Iran.

Abbas Pourhosein Gilakjani is a Ph.D. student of TESOL at the University Science Malaysia, Penang, Malaysia. He is also a faculty member of English Translation Department at the Islamic Azad University of Lahijan, Iran. He has taught English courses for over 13 years at 3 open universities in Guilan, Iran.

Sedigheh Sodouri is an M.A educational researcher over 20 years. She has taught over 20 years at university and the Ministry of Education, Tehran, Iran. 